\title{
Long memory or structural breaks: Can either explain nonstationary real exchange rates under the current float?
}

\author{
Christopher F. Baum ${ }^{1}$ \\ Boston College \\ Chestnut Hill, MA 02467 USA \\ John T. Barkoulas \\ Louisiana Tech University \\ Ruston, LA 71272 USA \\ Mustafa Caglayan \\ Koç University \\ Istanbul, Turkey
}

\begin{abstract}
This paper considers two potential rationales for the apparent absence of mean reversion in real exchange rates in the post-Bretton Woods era. We allow for (i) fractional integration and (ii) a double mean shift in the real exchange rate process. These methods, applied to CPI-based rates for 17 countries and WPI-based rates for 12 countries, demonstrate that the unit-root hypothesis is robust against both fractional alternatives and structural breaks. This evidence suggests rejection of the doctrine of absolute long-run purchasing power parity during the post-Bretton Woods era.

JEL: F31, C22.
\end{abstract}

Keywords: purchasing power parity, long memory, structural breaks.

1 Corresponding author: Christopher F. Baum, Department of Economics, Boston College, Chestnut Hill, MA 02467 USA, Tel: 617-552-3673, Fax 617-552-2308, email: baum@bc.edu. 


\section{Introduction}

The doctrine of purchasing power parity $(\mathrm{PPP})$ in its absolute form states that a common basket of goods, when quoted in the same currency, costs the same in all countries. $^{2}$ The parity condition rests on the assumption of perfect inter-country commodity arbitrage and is a central building block of many theoretical and empirical models of exchange rate determination. ${ }^{3}$ Due to factors like transaction costs, taxation, subsidies, restrictions on trade, the existence of nontraded goods, imperfect competition, foreign exchange market interventions, and the differential composition of market baskets and price indices across countries, one may expect PPP's implications to emerge only in the long-run. However, empirical studies generally fail to provide evidence supportive of long-run PPP in the post-Bretton Woods era.

A number of researchers have analyzed the long-run dynamics of real exchange rates in order to test the validity of long-run PPP, which implies that shocks to the real exchange rate must have only transitory effects. Contradicting this evidence, Corbae and Ouliaris (1988), Meese and Rogoff (1988), Edison and Fisher (1991), and Grilli and Kaminsky (1991) cannot reject the unit-root null hypothesis for real exchange rates in the managed float regime. However, Pedroni (1995), Frankel and Rose (1996), Lothian (1997), Oh (1996), and Wu (1996) find strong evidence of mean reversion in real exchange rates when panel data variants of standard unit-root tests are employed. These studies generally estimate the half-life of PPP deviations to be between three and five years. O'Connell (1998) strongly disputes these mean-reversion findings in real exchange rates since they fail to control for cross-sectional dependence in the data. He finds no evidence against the unit-root model in broad panels of real exchange rates when cross-sectional

2 Relative PPP, which is implied by absolute PPP, states that the rate of change in the nominal exchange rate equals the differential between the growth rates in home and foreign price indices.

3 See Rogoff (1996) for a review of the recent literature on PPP. 
dependencies are taken into account. In his judgment, "...the hypothesis of PPP is overvalued as a true characterization of real exchange rate behavior by tests which do not pay attention to cross-sectional dependence." (1998, p.12) Thus, the apparent success of panel unit root tests would be considered illusory, following O'Connell's argument. ${ }^{4}$

In this paper, we consider two other possible justifications for the strong evidence against PPP in the post-Bretton Woods era, in order to determine whether one or both of those factors, when taken into account, will overturn this generally impregnable evidence. First of all, we consider the possibility that the order of integration of the real exchange rate may be fractional, $I(d)$, rather than integer, $I(1)$ versus $I(0)$. The above studies allow for only integer orders of integration, creating a knife-edged unit-root versus stationarity distinction. However, the mean-reverting properties of real exchange rates may not be detectable by standard integer-order unit-root tests, which are well known to have low power against fractional alternatives. We employ a fractional integration framework to overcome this criticism while analyzing the low-frequency behavior of real exchange rates in the post-Bretton Woods era. Recently, Diebold, Husted, and Rush (1991) applied a single maximum likelihood method on more than a century of data from the classical gold standard period, ending in 1913. They found strong evidence of mean reversion in real exchange rates for six countries (U.S., U.K., Germany, France, Belgium, and Sweden) over this lengthy period. Our study focuses on a shorter but more homogenous time period, characterized by floating rates, for a broader set of countries' real exchange rates in order to determine whether allowing for fractional integration might yield evidence of mean reversion in the post-Bretton Woods era. In testing for fractional integration, we employ Sowell's (1992) exact maximum likelihood method.

A second potential explanation for the strength of unit-root evidence over this period has been put forth by Perron $(1990,1997)$ and Perron and Vogelsang (1992), who have

\footnotetext{
4 We must acknowledge an alternative explanation put forth by Pedroni (1997): that the constraint of a (1,1,-1) cointegrating vector in the construction of real exchange rate series is inappropriate. He shows that if heterogeneity in the cointegrating relationships is considered, there is evidence of 'weak PPP.' More importantly, he provides an alternative explanation for the misleading inference drawn from 'raw' panel unit-root tests.
} 
demonstrated that shifts in the intercept and/or slope of the trend function of a stationary time series biases standard unit-root tests toward nonrejection. ${ }^{5}$ As pointed out by Lothian (1998), the fundamental characteristic of U.S. dollar-based real exchange rates in the post-Bretton Woods era is their pattern during the 1980s: a substantial real dollar appreciation between 1980 and early 1985 followed by a nearly offsetting real dollar depreciation between 1985 and 1987. The stochastic movements of real exchange rates before 1980 and after 1987 appear to be much more stable (although not inconsequential). Lothian concludes that "...the problems of the current float were not, as commonly believed, generic to that system but in fact rather specific, being largely confined to one time period-the early and mid-1980s-and one currency-the U.S. dollar" (1998, p.29). The substantial variation in the levels of U.S. dollar-based real exchange rates in the 1980s may be indicative of a structural break in their timeseries representation which, if ignored, may have biased inference toward nonstationarity in conventional unit-root tests. A plausible process to model real exchange rates under the current float is a specification allowing for two changes in the mean of the stochastic process. ${ }^{6}$ Therefore, we apply Perron and Vogelsang's tests, as extended by Clemente et al. (1998) for double mean shifts, to evaluate the robustness of findings of nonstationarity in real exchange rates.

In summary, our study considers both fractional integration and structural breaks as possible explanations for findings of nonstationary behavior in post-Bretton Woods real exchange rates. Both of these explanations have been advanced by other researchers as plausible rationales for the failure to detect mean reversion in timeseries. However, none of the previous work has systematically investigated whether fractional integration, on the one hand, and structural breaks on the other are responsible for unit-root findings in a broad set of post-Bretton Woods real exchange rates. Therefore, our study extends the

\footnotetext{
5 Culver and Papell (1995) reject the unit-root hypothesis in favor of stationarity around a broken trend for real exchange rates under the gold standard.

6 We have tested for other types of structural breaks in the mean or trend of the real exchange rate process, but they do not alter the inference made in this research.
} 
literature in two important ways. First, we study a much broader set of real exchange rates than has been considered in much of the literature, including 17 CPI-based and 12 WPI-based measures over the post-Bretton Woods period. And second, we apply unit-root tests modified for the presence of fractional integration or structural breaks to ensure that findings of nonstationarity are not spurious reflections of instability in the relationship. Our findings from both fractional-differencing models and unit-root tests modified for structural breaks clearly indicate that the unit-root hypothesis is robust to the alternatives considered for real exchange rates over the post-Bretton Woods period, suggesting rejection of absolute PPP as a long-run equilibrium concept in this era.

The rest of the paper is constructed as follows. Section 2 reviews the empirical methodologies employed. Section 3 presents the data and the empirical estimates. Section 4 concludes with a summary of the evidence.

\section{Empirical Methodologies}

We first describe the fractional-differencing method employed, followed by the unitroot tests with double mean shifts taken into account.

\subsection{Fractional Differencing Estimation Methods}

The model of an autoregressive fractionally integrated moving average process of order $(p, d, q)$, denoted by $\operatorname{ARFIMA}(p, d, q)$, with mean $\mu$, may be written using operator notation as

$$
\Phi(L)(1-L)^{d}\left(y_{t}-\mu\right)=\Theta(L) u_{t}, u_{t} \sim i . i . d .\left(0, \sigma_{u}^{2}\right)
$$

where $L$ is the backward-shift operator, $\Phi(L)=1-\phi_{1} L-. .-\phi_{p} L^{p}, \Theta(L)=1+\vartheta_{1} L+$ $\ldots+\vartheta_{q} L^{q}$, and $(1-L)^{d}$ is the fractional differencing operator defined by 


$$
(1-L)^{d}=\sum_{k=0}^{\infty} \frac{\Gamma(k-d) L^{k}}{\Gamma(-d) \Gamma(k+1)}
$$

with $\Gamma(\cdot)$ denoting the gamma function. The parameter $d$ is allowed to assume any real value. The arbitrary restriction of $d$ to integer values gives rise to the standard autoregressive integrated moving average (ARIMA) model. The stochastic process $y_{t}$ is both stationary and invertible if all roots of $\Phi(L)$ and $\Theta(L)$ lie outside the unit circle and $|d|<0.5$. The process is nonstationary for $d \geq 0.5$, as it possesses infinite variance, i.e. see Granger and Joyeux (1980). Assuming that $d \in(0,0.5)$ and $d \neq 0$, Hosking (1981) showed that the correlation function, $\rho(\cdot)$, of an ARFIMA process is proportional to $k^{2 d-1}$ as $k \rightarrow \infty$. Consequently, the autocorrelations of the ARFIMA process decay hyperbolically to zero as $k \rightarrow \infty$ in contrast to the faster, geometric decay of a stationary ARMA process. For $d \in(0,0.5), \sum_{j=-n}^{n}|\rho(j)|$ diverges as $n \rightarrow \infty$, and the ARFIMA process is said to exhibit long memory, or long-range positive dependence. The process is said to exhibit intermediate memory (anti-persistence), or long-range negative dependence, for $d \in(-0.5,0)$. The process exhibits short memory for $d=0$, corresponding to stationary and invertible ARMA modeling. For $d \in[0.5,1)$ the process is mean reverting, even though it is not covariance stationary, as there is no long-run impact of an innovation on future values of the process.

We fit ARFIMA models to the series using Sowell's (1992) exact maximum likelihood (ML) method. This procedure allows for the simultaneous estimation of both the longmemory and ARMA parameters. Assuming normality of the innovations in (1), the $\log$ likelihood function for the sample of $T$ observations is given by

$$
L\left(\gamma ; Y_{T}\right)=-\frac{T}{2} \log (2 \pi)-\frac{1}{2} \log \left|\Sigma_{T}\right|-\frac{1}{2}\left(Y_{T}^{\prime} \Sigma_{T}^{-1} Y_{T}\right)
$$

The ML estimator, which is obtained by maximizing (3) with respect to the parameter vector $\gamma=\{\Phi, \Theta, d\}$, is consistent and asymptotically normal. The covariance function 
$\Sigma_{T}$ is a complicated function of the parameters of the model $\gamma$ and each evaluation of the likelihood function requires the inversion of the $(T \times T)$ matrix $\Sigma_{T}$, which is computationally burdensome. Sowell utilized the Toeplitz structure of $\Sigma_{T}$ to alleviate this burden; that article contains details on the derivation of the likelihood function for a fractionally differenced process, computational considerations, and the small sample properties of the exact ML estimates.

\subsection{Unit-Root Tests Modified for Structural Breaks}

Perron and Vogelsang (1992), building on work by Perron (1990), demonstrate that nonrejection of the unit-root hypothesis may be "associated with an apparent permanent change in the level of the series" $(1992$, p. 302). As Perron demonstrated with a simulation experiment, "...if the magnitude of the change is significant, one could hardly reject the unit-root hypothesis even if the series would consist of iid disturbances around a deterministic component (albeit one with a shift in mean)...The problem is one of model misspecification." (1990, p.155) To deal with this source of bias in unit-root tests, Perron and Vogelsang propose a class of test statistics which allow for two alternative forms of change: the "additive outlier" ( $\mathrm{AO}$ ) model, capturing a sudden change, and the "innovational outlier" (IO) model, appropriate for modeling a gradual shift in the mean of the series. The test statistics do not require a priori knowledge of the breakpoint, as their computation involves search over the sample for a single break date. The breakpoint, should it occur, is denoted by $T_{b}, 1<T_{b}<T$, where $T$ is the sample size. The AO model considers the dynamics of $y_{t}$ to be given by

$$
y_{t}=\delta D T_{b t}+y_{t-1}+w_{t}, t=2, \ldots, T
$$

with $D T_{b t}=1$ for $t=T_{b}+1$, and 0 otherwise, under the null hypothesis of a unit root. 
Under the alternative hypothesis,

$$
y_{t}=c+\delta D U_{t}+v_{t}, t=2, \ldots, T
$$

where $D U_{t}=1$ for $t>T_{b}$, and 0 otherwise. This more general specification nests the null hypothesis (4) in the case that the distribution of $v_{t}$ may be factored into a unit root and a stationary ARMA process. The test strategy is then to estimate the regression

$$
y_{t}=\mu+\delta D U_{t}+\tilde{y}_{t}
$$

the residuals of which $\left(\tilde{y}_{t}\right)$ are regressed on their lagged values, lagged differences, and a set of dummy variables, the latter needed to ensure that the distribution of the test statistic will be manageable:

$$
\tilde{y}_{t}=\sum_{i=0}^{k} \omega_{i} D T_{b t-i}+\alpha \tilde{y}_{t-1}+\sum_{i=1}^{k} \theta_{i} \Delta \tilde{y}_{t-i}+e_{t}, t=k+2, \ldots, T
$$

This regression, similar in nature to the common Augmented Dickey-Fuller (ADF) model, yields an estimate of $\alpha$ which will be significantly less than one in the presence of stationarity. Perron and Vogelsang provide critical values and describe the method by which they may be simulated.

The equivalent process for the innovational outlier (IO) model expresses the shock (for instance, the effect of $\delta$ in (4) above) as having the same effect on $y_{t}$ as any other shock, so that the dynamic effects of $D T_{b}$ have the same ARMA representation as do other shocks to the model. This formulation, when transformed, generates the finite AR model

$$
y_{t}=\mu+\delta D U_{t}+\vartheta D T_{b t}+\alpha y_{t-1}+\sum_{i=1}^{k} \theta_{i} \Delta y_{t-i}+e_{t}, t=k+2, \ldots, T
$$

which again yields a test of $\alpha$ differing from one in the presence of stationarity. In both the $\mathrm{AO}$ and the IO models, the appropriate values of $T_{b}$ (the breakpoint) and $k$ (the autoregressive order) are unknown. This is resolved for $T_{b}$ by estimating the model 
for each feasible breakpoint, and following one of several proposed rules to identify the optimal single breakpoint. In our application, we search for the minimum t-statistic on $\delta$. Conditional on that $T_{b}$, the autoregressive order $k$ is chosen, as Perron (1990) suggests, by a sequence of pairs of F-tests for the significance of lags, starting from an appropriately large maximum order.

The unit-root test statistics forthcoming from the AO and IO models will account for one-time level shifts which might otherwise be identified as departures from stationarity. However, the behavior of real exchange rate series over our sample period may not be adequately characterized by a single shift; as Lothian (1998) has noted, US dollarbased real exchange rates appear to have exhibited two shifts in mean over the 1980-1987 period, approximately reverting to their pre-1980 level after 1987. In these circumstances, allowing for a single level shift will not suffice. The Perron-Vogelsang methodology has been extended to double mean shifts by Clemente et al. (1998), who demonstrate that a two-dimensional grid search for breakpoints $\left(T_{b 1}\right.$ and $\left.T_{b 2}\right)$ may be used for either the AO or IO models, and provide critical values for the tests. In this context, the AO model involves the estimation of:

$$
y_{t}=\mu+\delta_{1} D U_{1 t}+\delta_{2} D U_{2 t}+\tilde{y}_{t}
$$

and subsequently searching for the minimal $t$-ratio for the hypothesis $\alpha=1$ in the model:

$$
\tilde{y}_{t}=\sum_{i=0}^{k} \omega_{1 i} D T_{b 1, t-i}+\sum_{i=0}^{k} \omega_{2 i} D T_{b 2, t-i}+\alpha \tilde{y}_{t-1}+\sum_{i=1}^{k} \theta_{i} \Delta \tilde{y}_{t-i}+e_{t}, t=k+2, \ldots, T
$$

For the IO model, the modified equation to be estimated becomes:

$$
y_{t}=\mu+\delta_{1} D U_{1 t}+\delta_{2} D U_{2 t}+\vartheta_{1} D T_{b 1, t}+\vartheta_{2} D T_{b 2, t}+\alpha y_{t-1}+\sum_{i=1}^{k} \theta_{i} \Delta y_{t-i}+e_{t}, t=k+2, \ldots, T
$$


with a search for the minimal $t$-ratio for the hypothesis $\alpha=1 .^{7}$

\section{$3 \quad$ Data and Empirical Estimates}

\subsection{Data}

The real exchange rate expresses the value of a currency in terms of real purchasing power. At time $t$, the real exchange rate, denoted by $r_{t}$, is defined as

$$
r_{t}=\frac{S_{t} P_{t}^{*}}{P_{t}}
$$

where $S_{t}$ is the domestic price of foreign currency at time $t$ and $P_{t}$ and $P_{t}^{*}$ are the domestic and foreign price levels, respectively, at time $t$. Both the consumer (CPI) and wholesale (WPI) price indices are used as proxies for the price levels of each country's output.

All series are extracted from the International Monetary Fund's International Financial Statistics database and span the period August 1973 to December 1995 for a total of 269 monthly observations. The CPI real exchange rates considered are for seventeen industrial countries: Canada, Germany, the United Kingdom, France, Italy, Japan, Austria, Belgium, Denmark, the Netherlands, Norway, Sweden, Switzerland, Finland, Greece, Portugal, and Spain. The WPI-based real exchange rates may be constructed for only twelve of these countries: Canada, Germany, the United Kingdom, Japan, Austria, Denmark, the Netherlands, Norway, Sweden, Finland, Greece, and Spain. In all cases, the United States is considered the home country.

\footnotetext{
7 These tests customarily are applied to a trimmed sample; we trimmed $5 \%$ of the sample from each end when searching for the breakpoints.
} 


\subsection{Fractional-Differencing Estimates}

A possible explanation for the failure to reject the unit-root hypothesis in real exchange rates under the current float is the restrictiveness of standard unit-root tests regarding admissible low-frequency dynamic behavior. These tests, in allowing for only integer orders of integration in the series dynamics, are likely to have low power against fractional alternatives. Diebold and Rudebusch (1991) demonstrated that the commonly applied Dickey-Fuller test (Dickey and Fuller, 1981) exhibits this weakness. By contrast, fractionally integrated models allow the integration order of a series to take any value on the real line. By doing so, the knife-edged $I(1)$ versus $I(0)$ distinction is avoided and a wider range of mean-reverting dynamics can be detected by hypothesis tests on the fractional-differencing parameter.

If the (log) real exchange rates in (12) follow a stationary ARMA process, then deviations from parity are transitory and long-run PPP holds. However, if real exchange rates contain a unit root, then deviations from parity will accumulate over time and no reversion to parity occurs. Since real exchange rate series need not be exactly $I(0)$ or $I(1)$ processes, but they may be integrated of order $d, d \in(0,1)$, in which case they will exhibit the long-memory property. Therefore, a $d$ estimate less than unity would confirm the existence of long-run PPP, since a shock to the real exchange rate series would not persist indefinitely but would eventually dissipate, giving rise to mean-reverting behavior. We estimate the fractional-integration model using the logarithmic differences of the real exchange rate series in (12) in order to ensure that stationarity and invertibility conditions are met. Consequently, a significantly negative long-memory estimate for the differenced series, $d^{*}$, would be consistent with long-run parity reversion, as the long-memory parameter for the levels series is given by $d=1+d^{*}$.

Table 1 reports the exact ML fractional exponent estimates for the CPI real exchange rate series, while Table 2 reports the equivalent estimates for the WPI-based real exchange rates. ${ }^{8}$ Following Schmidt and Tscherning's (1993) recommendation that no

8 We have also estimated the fractional-differencing parameter for both CPI-based and WPI-based real exchange 
single information criterion systematically dominates in identifying the correct ARFIMA model, the final ARFIMA $\left(p, d^{*}, q\right)$ model is selected on the basis of both Akaike (AIC) and Schwarz (SIC) information criteria. We have ensured that stationarity and invertibility conditions are met and checked for near-redundancies in the AR and MA polynomials. The maximum order allowed in the AR and MA polynomials is three, that is, $p \leq 3$ and $q \leq 3$.

The ML evidence strongly supports the presence of a unit root in the autoregressive polynomial of the real exchange rate series. Regardless of the information criterion employed to choose the final ARFIMA specification, there is no evidence of mean reversion in any of the series at the five per cent level, as none of the estimated long-memory parameters is statistically significant at that level. ${ }^{9}$ The obtained evidence therefore overwhelmingly rejects the long-run parity condition. In most cases, a pure martingale model appears to be an appropriate characterization of the dynamic behavior of the series.

\subsection{Structural Break Estimates}

We applied the Clemente et al. (1998) generalizations of the Perron-Vogelsang procedures,$^{10}$ allowing for double mean shifts in the series via estimation of (10) and (11) for the AO and IO models, respectively. To motivate the usefulness of a double shift in the mean of real exchange rates and illustrate Lothian's (1998) stylized facts of the dynamic behavior of these series, we present graphs of real exchange rates for selected countries. Figure 1 presents the CPI-based real exchange rates for Germany, Italy, Austria, and

rates using two periodogram methods: the spectral regression (Geweke and Porter-Hudak, 1983) and the Gaussian semiparametric (Robinson, 1995). The inference drawn regarding the low-frequency dynamics of real exchange rates remains unaltered when these estimates of the fractional differencing parameter are considered (results available upon request).

9 Absence of mean reversion in both CPI- and WPI-based real exchange rates does not depend on the shortmemory (ARMA) specification, as the long-memory parameter remains statistically insignificant for alternative ARMA structures.

10 The original Perron-Vogelsang procedures were also applied; the results never supported stationarity in the series with a single break in mean for either the AO or IO model. 
Portugal, while Figure 2 presents the WPI-based real exchange rates for Japan, Netherlands, Sweden, and Spain. These graphs clearly reflect the episodic behavior of the U.S. dollar in the 1980s and the plausibility of a double shift in the mean of the exchange rate process as an alternative to the unit-root null. ${ }^{11}$

The results of these unit-root tests are presented in Tables 3 and 4 for the CPI-based series and in Tables 5 and 6 for the WPI-based series. The additive outlier (AO) model results in Tables 3 and 5 report the breakpoints $T_{b 1}$ and $T_{b 2}$, the autoregressive order $(k)$ chosen, estimates of $\mu, \delta_{1}$ and $\delta_{2}$ from (9), the estimate of $\alpha-1$ from (10), and the unitroot test statistic, $t_{\alpha-1}$. The $\delta$ estimates, indicating the importance of mean shifts, are uniformly distinguishable from zero for both CPI-based and WPI-based real exchange rates. For every country except Japan and Canada, an initial downward shift in the early 1980s is followed by an upward shift in the mid-1980s in the CPI-based series. For the WPI-based series, even greater similarities are visible, with all countries but Canada and the U.K. experiencing a downward shift in 1981-1982, with a reversal in 1985-1987. None of the unit-root test statistics approach the $5 \%$ critical value of -5.49 , indicating that unit-roots in these real exchange rate series cannot be rejected.

The results for the IO model (11) are presented in Tables 4 and 6, and report the breakpoints $T_{b 1}$ and $T_{b 2}$, the autoregressive order $(k)$ chosen, and estimates of $\mu, \delta_{1}, \delta_{2}$, and $\alpha-1$ as well as the unit-root test statistic, $t_{a-1}$. While evidence for two mean shifts is weaker in the innovational outlier context, most of the $\delta_{1}$ and $\delta_{2}$ estimates indicate the presence of mean shifts in both CPI- and WPI-based series (with the possible exception of Canada's CPI-based series). The CPI-based series exhibit downward shifts in the early 1980s for all countries but Japan and Canada, with reversal (for all but Japan and Canada) in 1986-1987. For the WPI-based series, an initial decline in the mean in

\footnotetext{
11 As suggested by an anonymous reviewer, this sequence of real exchange rate levels might also be characterized in a breaking trend context: prior to 1980 and since 1987, no discernable trend appears in the US dollar-based real exchange rates. In the interim period, rates were characterized by somewhat steady growth followed by somewhat steady decline. This implies that a model incorporating three breaks in trend would be required. Although the literature contains test procedures for single trend breaks, the analytics to evaluate multiple trend breaks in a unit-root test have not yet been developed.
} 
1981-1982 is evident for all countries but Canada, U.K., and Japan, with a reversal in 1985-1987. None of the unit-root test statistics approach the $5 \%$ critical value of -5.49 , indicating that accounting for two level shifts with the innovational outlier model does not strengthen the evidence against the unit-root null.

The results from these two-mean-break models are quite consistent over countries and price series. In none of the 58 cases considered do the unit-root test statistics surpass their approximate $5 \%$ critical values, although the t-statistics for $\delta_{1}$ and $\delta_{2}$ generally indicate the presence of meaningful level shifts in almost every instance. Even with structural breaks taken into account, the evidence in favor of nonstationarity is overwhelmingly strong and consistent across countries for both CPI-based and WPI-based real exchange rate series. Therefore, we may conclude that the inability to reject the unit-root hypothesis for the post-Bretton Woods era using standard univariate unit-root tests is not likely to be overturned by allowing for one or two mean breaks in the series. Such instability is quite apparent in a first-order Markov model of the real exchange rate, but even when unit-root tests are adjusted for its presence, the null hypothesis of nonstationarity cannot be rejected in favor of mean reversion.

\section{Conclusions}

This paper investigates whether the doctrine of absolute purchasing power parity holds as a long-run equilibrium concept during the post-Bretton Woods period of flexible exchange rates. In contrast to the literature, we allow for more flexible and realistic alternatives against which to test the unit-root null hypothesis. More specifically, we allow for fractional dynamic behavior and double mean shifts in the time series representation of both CPI-based and WPI-based real exchange rates for a number of industrial countries. Nevertheless, the evidence does not support absolute long-run PPP, regard-

less of the country, choice of price index, estimation methodology, or alternative to the 
unit-root hypothesis considered. However, it is possible that our ability to detect mean reversion in this period may be weakened by its brevity. Consistent with Frankel (1990), if deviations from PPP damp sufficiently slowly, it may require many decades of data in order to reliably reject the unit-root null hypothesis in real exchange rates. ${ }^{12}$ Given the length of the post-Bretton Woods era in terms of calendar time, real exchange rates may not display a sufficient degree of mean reversion to enable us to reliably distinguish very slow mean reversion from a unit-root process, especially in light of the episodic behavior of the U.S. dollar in the 1980s. Unfortunately, in order to obtain a sample for the floating exchange rate period which would support stronger inferences on long-run PPP, we may have no remedy but to wait. Our results must be interpreted in light of this criticism.

\section{Acknowledgements}

We acknowledge the helpful comments of Antonio Montañes, Peter Pedroni, an anonymous reviewer, and the editor of this journal. The standard disclaimer applies.

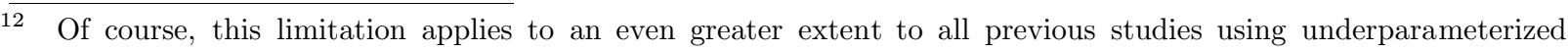
alternatives to the unit-root null hypothesis in real exchange rates.
} 


\section{References}

[1] Clemente, J., Montañes, A. and M. Reyes (1998), Testing for a unit root in variables with a double change in the mean, Economics Letters, 59, 175-182.

[2] Corbae, D. and S. Ouliaris (1988), Cointegration and tests of purchasing power parity, Review of Economics and Statistics, 70, 508-511.

[3] Culver, S. and D. Papell (1995), Real exchange rates under the gold standard: Can they be explained by the trend break model? Journal of International Money and Finance, 14, 539-548.

[4] Dickey, D. A. and W. A. Fuller (1981), Likelihood ratio statistics for autoregressive time series with a unit root, Econometrica, 49, 1057-1072.

[5] Diebold, F. X., Husted, S. and Rush, M. (1991), Real exchange rates under the gold standard, Journal of Political Economy, 99, 1252-1271.

[6] Diebold, F. X. and G. D. Rudebusch (1991), On the power of Dickey-Fuller tests against fractional alternatives, Economics Letters, 35, 155-160.

[7] Edison, H. J. and E. O. Fisher (1991), A long-run view of the European monetary system, Journal of International Money and Finance, 10, 53-70.

[8] Frankel, J. A. (1990), Zen and the art of modern macroeconomics: A commentary, in Monetary Policy for a Volatile Global Economy, W. S. Haraf and T. A. Willett, eds., pp.117-123, The AEI Press, Washington, DC.

[9] Frankel, J. A. and A. Rose (1996), Mean reversion within and between countries: A panel project on purchasing power parity, Journal of International Economics, 40, 209-224.

[10] Geweke J. and S. Porter-Hudak (1983), The estimation and application of long memory time series models, Journal of Time Series Analysis, 4, 221-238.

[11] Granger, C. W. J. and R. Joyeux (1980), An introduction to long-memory time series models and fractional differencing, Journal of Time Series Analysis, 1, 15-39.

[12] Grilli, V. and G. Kaminsky (1991), Nominal exchange rates regimes and the real exchange rate, Journal of Monetary Economics, 27, 191-212.

[13] Hosking, J. R. M. (1981), Fractional differencing, Biometrika, 68, 165-176.

[14] Lothian, J. (1997), Multi-country evidence on the behavior of purchasing power parity under the current float, Journal of International Money and Finance, 16, 19-35.

[15] Lothian, J. (1998), Some new stylized facts of floating exchange rates, Journal of International Money and Finance, 17, 29-39.

[16] Meese, R. A. and K. S. Rogoff (1988), Was it real? The exchange-rate interest differential relation over the modern floating rate period, Journal of Finance, 43, 933-948.

[17] O'Connell, P. G. (1998), The overvaluation of purchasing power parity, Journal of International Economics, 44, 1-19. 
[18] Oh, K.-Y. (1996), Purchasing power parity and unit root tests using panel data, Journal of International Money and Finance, 15, 405-418.

[19] Pedroni, P. (1995), Panel cointegration: Asymptotic and finite sample properties of pooled time series tests with an application to the PPP hypothesis, Unpublished working paper 95-013, Department of Economics, Indiana University.

[20] Pedroni, P. (1997), Fully modified OLS for heterogeneous cointegrated panels and the case of purchasing power parity, Unpublished working paper 96-020, Department of Economics, Indiana University.

[21] Perron, P. (1990), Testing for a unit root in a time series with a changing mean, Journal of Business and Economic Statistics, 8:2, 153-162.

[22] Perron, P. (1997), Further evidence on breaking trend functions in macroeconomic variables, Journal of Econometrics, 80, 355-385.

[23] Perron, P. and T. Vogelsang (1992), Nonstationarity and level shifts with an application to purchasing power parity, Journal of Business and Economic Statistics, 10:3, 301-320.

[24] Robinson, P. (1995), Gaussian semiparametric estimation of long range dependence, Annals of Statistics, 23, 1630-1661.

[25] Rogoff, K. S. (1996), The purchasing power parity puzzle, Journal of Economic Literature, 34, 647-668.

[26] Schmidt, C. M. and R. Tscherning (1993), Identification of fractional ARIMA models in the presence of long memory, Working paper no. 93-04, University of Munich.

[27] Sowell, F. (1992), Maximum likelihood estimation of stationary univariate fractionallyintegrated time-series models, Journal of Econometrics, 53, 165-188.

[28] Wu, Y. (1996), Are real exchange rates nonstationary? Evidence from panel-data tests, Journal of Money, Credit, and Banking, 28, 54-63. 
Table 1: Exact Maximum Likelihood Estimates of the Fractional Differencing Parameter $d^{*}$ for CPI-based Real Exchange Rates

$\begin{array}{lllll}\text { Country } & \begin{array}{l}\text { ARMA }(p, q) \\ \text { Order }\end{array} & \begin{array}{l}\text { Long Memory } \\ \text { Parameter } d^{*}\end{array} & \begin{array}{l}\text { Standard Error } \\ \text { for } d^{*} \text { Estimate }\end{array} & \begin{array}{l}H_{0}: d^{*}=0 \\ \text { Canada }\end{array} \\ & (0,2) & 0.205 & 0.179 & 1.148 \\ \text { Germany } & (1,0) & 0.016 & 0.067 & 0.249 \\ \text { United Kingdom } & (0,0) & 0.026 & 0.048 & 0.548 \\ \text { France } & (0,0) & 0.044 & 0.052 & 0.840 \\ \text { Italy } & (0,0) & 0.022 & 0.047 & 0.460 \\ \text { Japan } & (0,0) & 0.055 & 0.049 & 1.103 \\ \text { Austria } & (0,0) & 0.078 & 0.052 & 1.508 \\ \text { Belgium } & (0,0) & 0.027 & 0.049 & 0.550 \\ \text { Denmark } & (0,0) & 0.042 & 0.047 & 0.878 \\ & (3,1) & -0.064 & 0.141 & -0.454 \\ \text { Netherlands } & (0,0) & 0.029 & 0.047 & 0.610 \\ \text { Norway } & (0,0) & 0.021 & 0.049 & 0.434 \\ & (1,3) & -0.144 & 0.083 & -1.720^{*} \\ \text { Sweden } & (0,0) & 0.008 & 0.050 & 0.160 \\ \text { Switzerland } & (0,0) & 0.045 & 0.049 & 0.927 \\ \text { Finland } & (0,0) & 0.032 & 0.050 & 0.634 \\ \text { Greece } & (0,0) & 0.033 & 0.048 & 0.678 \\ \text { Portugal } & (1,1) & -0.060 & 0.050 & -1.197 \\ \text { Spain } & (1,0) & -0.021 & 0.082 & -0.266 \\ & (0,0) & 0.032 & 0.046 & 0.704\end{array}$

Notes: The data for the CPI real exchange series cover the period 07/1973 to 12/1995 for a total of 269 monthly observations. The exact ML method is that proposed by Sowell (1992), and is applied to the first differences of the logarithms of the real exchange rate series. If the AIC and SIC criteria choose different models, the first row presents the model chosen by the AIC criterion while the second row presents the model chosen by the SIC criterion. The superscripts ${ }^{* *},{ }^{* *},{ }^{*}$ indicate statistical significance at the 1,5 , and 10 per cent levels, respectively. 
Table 2: Exact Maximum Likelihood Estimates of the Fractional Differencing Parameter $d^{*}$ for WPI-based Real Exchange Rates

$\begin{array}{lllll}\text { Country } & \begin{array}{l}\text { ARMA }(p, q) \\ \text { Order }\end{array} & \begin{array}{l}\text { Long Memory } \\ \text { Parameter } d^{*}\end{array} & \begin{array}{l}\text { Standard Error } \\ \text { for } d^{*} \text { Estimate }\end{array} & \begin{array}{l}\text { t-statistic for } \\ H_{0}: d^{*}=0\end{array} \\ \text { Canada } & (0,2) & 0.063 & 0.164 & 0.390 \\ \text { Germany } & (1,0) & -0.100 & 0.073 & -1.370 \\ \text { United Kingdom } & (0,0) & 0.014 & 0.050 & 0.285 \\ & (0,1) & -0.079 & 0.073 & -1.075 \\ \text { Japan } & (0,0) & 0.023 & 0.054 & 0.431 \\ \text { Austria } & (0,2) & 0.005 & 0.051 & 0.113 \\ & (1,0) & -0.130 & 0.085 & -1.538 \\ \text { Denmark } & (1,0) & -0.041 & 0.095 & -0.431 \\ \text { Netherlands } & (0,0) & 0.009 & 0.079 & 0.119 \\ \text { Norway } & (0,2) & -0.141 & 0.049 & 0.105 \\ & (0,0) & -0.003 & 0.081 & -1.724^{*} \\ \text { Sweden } & (0,0) & 0.024 & 0.051 & -0.062 \\ \text { Finland } & (0,0) & 0.012 & 0.051 & 0.466 \\ \text { Greece } & (3,1) & -0.175 & 0.051 & 0.242 \\ \text { Spain } & (1,0) & -0.043 & 0.140 & -1.242 \\ & (0,0) & 0.008 & 0.092 & -0.472 \\ & & & 0.048 & 0.169\end{array}$

Notes: The data for the WPI real exchange series cover the period 07/1973 to 12/1995 for a total of 269 monthly observations. See notes in Table 1 for additional explanation of the table. 
Table 3: Additive Outlier Unit-root Tests for CPI-Based

Real Exchange Rate Series

\begin{tabular}{|c|c|c|c|c|c|c|c|}
\hline $\begin{array}{l}\text { Country } \\
\text { Canada }\end{array}$ & $\begin{array}{l}\delta_{1} \\
-0.127 \\
(-14.58)\end{array}$ & $\begin{array}{l}T_{b 1} \\
1997: 11\end{array}$ & $\begin{array}{l}\delta_{2} \\
-0.113 \\
(-9.61)\end{array}$ & $\begin{array}{l}T_{b 2} \\
1993: 11\end{array}$ & $\begin{array}{l}\mu \\
-0.112\end{array}$ & $\begin{array}{l}k \\
0\end{array}$ & $\begin{array}{l}\alpha-1 \\
-0.050 \\
(-2.57)\end{array}$ \\
\hline Germany & $\begin{array}{l}-0.373 \\
(-24.29)\end{array}$ & 1981:02 & $\begin{array}{l}0.313 \\
(21.41)\end{array}$ & 1986:04 & -0.463 & 0 & $\begin{array}{l}-0.122 \\
(-3.90)\end{array}$ \\
\hline nited Kingdom & $\begin{array}{l}-0.266 \\
(-8.85)\end{array}$ & 1984:01 & $\begin{array}{l}0.325 \\
(10.82)\end{array}$ & 1985:07 & 0.408 & 0 & $\begin{array}{l}-0.074 \\
(-3.20)\end{array}$ \\
\hline rance & $\begin{array}{l}-0.357 \\
(-23.20)\end{array}$ & 1982:03 & $\begin{array}{l}0.330 \\
(21.84)\end{array}$ & 1986:04 & -1.712 & 0 & $\begin{array}{c}-0.139 \\
(-4.31)\end{array}$ \\
\hline aly & $\begin{array}{l}-0.211 \\
(-13.77)\end{array}$ & 1981:08 & $\begin{array}{l}0.339 \\
(22.82)\end{array}$ & 1986:04 & -7.337 & 0 & $\begin{array}{l}-0.107 \\
(-3.79)\end{array}$ \\
\hline apan & 45 & 1986:04 & $\begin{array}{l}0.225 \\
(-9.60)\end{array}$ & 1993:05 & -5.236 & 0 & $\begin{array}{l}.075 \\
3.19)\end{array}$ \\
\hline ustr & $\begin{array}{l}-0.299 \\
(-19.15)\end{array}$ & 1981:02 & $\begin{array}{l}0.367 \\
(24.68)\end{array}$ & 1986:04 & 2.518 & 0 & $\begin{array}{l}-0.116 \\
(-3.83)\end{array}$ \\
\hline elgium & -0.448 & 1981:08 & $\begin{array}{l}0.340 \\
(20.04)\end{array}$ & 1986:04 & -3.434 & 0 & $\begin{array}{l}-0.125 \\
(-4.14)\end{array}$ \\
\hline enmark & $\begin{array}{l}355 \\
2.53)\end{array}$ & 1981:08 & $\begin{array}{l}0.375 \\
(24.58)\end{array}$ & 1986:04 & -1.900 & 0 & $\begin{array}{l}-0.136 \\
(-4.31)\end{array}$ \\
\hline Netl & $\begin{array}{l}-0.363 \\
(-23.11)\end{array}$ & 1981:02 & $\begin{array}{l}0.272 \\
(18.13)\end{array}$ & 1986:04 & -0.523 & 0 & $\begin{array}{l}-0.113 \\
(-3.80)\end{array}$ \\
\hline Torwa & $\begin{array}{l}-0.258 \\
(-19.82)\end{array}$ & 1982:03 & $\begin{array}{l}0.261 \\
(20.40)\end{array}$ & 1986:04 & -1.912 & 0 & $\begin{array}{l}-0.148 \\
(-4.47)\end{array}$ \\
\hline weden & $\begin{array}{l}-0.418 \\
(-25.50)\end{array}$ & 1982:03 & $\begin{array}{l}0.316 \\
(19.64)\end{array}$ & 1986:04 & -1.781 & 6 & $\begin{array}{l}-0.137 \\
(-3.65)\end{array}$ \\
\hline witz & -0.245 & 1982:11 & $\begin{array}{l}0.388 \\
(18.15)\end{array}$ & 1986:04 & -0.486 & 0 & $\begin{array}{l}-0.087 \\
(-3.36)\end{array}$ \\
\hline inl & $\begin{array}{l}-0.239 \\
(-12.50)\end{array}$ & 1982:11 & $\begin{array}{l}0.306 \\
(16.11)\end{array}$ & 1986:04 & -1.588 & 0 & $\begin{array}{c}-0.083 \\
(-3.38)\end{array}$ \\
\hline Greece & $\begin{array}{l}-0.343 \\
(-21.03)\end{array}$ & 1982:10 & $\begin{array}{l}0.336 \\
(20.62)\end{array}$ & 1986:09 & -5.089 & 12 & $\begin{array}{l}-0.117 \\
(-2.81)\end{array}$ \\
\hline Portugal & -0.365 & 1982:03 & $\begin{array}{l}0.424 \\
(22.69)\end{array}$ & 1986:09 & -5.033 & 0 & $\begin{array}{l}-0.099 \\
(-3.56)\end{array}$ \\
\hline opail & $\begin{array}{l}-0.331 \\
(-15.64)\end{array}$ & 10 & $\begin{array}{l}0.461 \\
(21.94)\end{array}$ & 1986:04 & -4.877 & 0 & $\begin{array}{l}-0.092 \\
(-3.50)\end{array}$ \\
\hline
\end{tabular}

Notes: The unit-root tests are those proposed by Clemente et al. (1998) for the 
additive outlier (AO) model of a unit-root in the presence of double mean shifts, as given in equations (9) and (10) above. The critical value for $t_{\alpha}$ is approximately -5.49 for the $5 \%$ level of significance (op.cit., Table 2). The t-statistics for $\mu, \delta_{1}$ and $\delta_{2}$ follow a standard t-distribution under the null. $k$ is the autoregressive lag order chosen. See notes in Table 1 for data details. 
Table 4: Innovational Outlier Unit-root Tests for CPI-Based Real Exchange Rate Series

$\begin{array}{llllllll}\text { Country } & \delta_{1} & T_{b 1} & \delta_{2} & T_{b 2} & \mu & k & \alpha-1 \\ \text { Canada } & -0.004 & 1978: 03 & -0.004 & 1993: 09 & -0.008 & 11 & -0.048 \\ & (-1.44) & & (-1.22) & & & & (-3.04) \\ \text { Germany } & -0.020 & 1981: 04 & 0.021 & 1986: 07 & -0.030 & 0 & -0.061 \\ & (-1.93) & & (-2.32) & & & & (-2.62) \\ \text { United Kingdom } & -0.013 & 1982: 11 & 0.018 & 1987: 10 & 0.032 & 11 & -0.073 \\ & (-1.81) & & (2.25) & & & & (-3.33) \\ \text { France } & -0.026 & 1982: 04 & 0.028 & 1986: 03 & -0.125 & 0 & -0.073 \\ & (-2.57) & & (2.87) & & & & (-3.15) \\ \text { Italy } & -0.011 & 1981: 05 & 0.021 & 1986: 05 & -0.467 & 0 & -0.063 \\ & (-1.54) & & (2.37) & & & & (-2.90) \\ \text { Japan } & 0.022 & 1986: 02 & 0.014 & 1993: 02 & -0.358 & 11 & -0.069 \\ & (2.75) & & (1.69) & & & & (-3.37) \\ \text { Austria } & -0.013 & 1981: 05 & 0.020 & 1986: 07 & -0.135 & 0 & -0.053 \\ & (-1.44 & & (2.02) & & & & (-2.36) \\ \text { Belgium } & -0.023 & 1981: 05 & 0.020 & 1986: 07 & -0.185 & 0 & -0.054 \\ & (-2.07 & & (2.24) & & & & (-2.54) \\ \text { Denmark } & -0.023 & 1981: 05 & 0.027 & 1986: 07 & -0.137 & 2 & -0.072 \\ & (-2.29) & & (2.68) & & & & (-3.03) \\ \text { Netherlands } & -0.024 & 1981: 04 & 0.020 & 1986: 07 & -0.038 & 2 & -0.071 \\ & (-2.31) & & (2.41) & & & & (-3.01) \\ \text { Norway } & -0.033 & 1982: 06 & 0.035 & 1986: 11 & -0.249 & 9 & -0.130 \\ & (-3.54) & & (3.76) & & & & (-4.25) \\ \text { Sweden } & -0.033 & 1982: 01 & 0.026 & 1986: 07 & -0.153 & 9 & -0.086 \\ & (-2.98) & & (2.93) & & & & (-3.61) \\ \text { Switzerland } & -0.019 & 1982: 04 & 0.029 & 1986: 07 & -0.038 & 11 & -0.084 \\ \text { Finland } & (-2.02) & & (2.55) & & & & (-3.25) \\ & -0.014 & 1982: 08 & 0.018 & 1986: 02 & -0.112 & 11 & -0.071 \\ \text { Greece } & (-1.76) & & (2.09) & & & & (-3.36) \\ & -0.020 & 1982: 06 & 0.023 & 1987: 01 & -0.373 & 12 & -0.073 \\ \text { Portugal } & (-2.00) & & (2.38) & & & & (-2.82) \\ & -0.020 & 1982: 04 & 0.027 & 1987: 01 & -0.303 & 11 & -0.060 \\ \text { Spain } & (-2.04) & & (2.55) & & & & (-2.73) \\ & -0.012 & 1982: 07 & 0.020 & 1986: 07 & -0.216 & 0 & -0.044 \\ & (-1.45) & & (2.03) & & & & (-2.43) \\ & & & & & & & \end{array}$

Notes: The unit-root tests are those proposed by Clemente et al. (1998) for the 
innovational outlier (IO) model of a unit-root in the presence of double mean shifts, as given in equation (11) above. The critical value for $t_{\alpha}$ is approximately -5.49 for the $5 \%$ level of significance (op.cit., Table 1). The t-statistics for $\mu, \delta_{1}$ and $\delta_{2}$ follow a standard t-distribution under the null. $k$ is the autoregressive lag order chosen. See notes in Table 1 for data details. 
Table 5: Additive Outlier Unit-root Tests for WPI-Based Real Exchange Rate Series

$\begin{array}{llllllll}\text { Country } & \delta_{1} & T_{b 1} & \delta_{2} & T_{b 2} & \mu & k & \alpha-1 \\ \text { Canada } & -0.108 & 1977: 11 & 0.067 & 1987: 03 & -0.153 & 11 & -0.100 \\ & (-17.12) & & (13.16) & & & & (-3.12) \\ \text { Germany } & -0.290 & 1981: 02 & 0.377 & 1986: 04 & -0.603 & 0 & -0.150 \\ & (-20.77) & & (28.33) & & & & (-4.43) \\ \text { United Kingdom } & -0.145 & 1984: 01 & 0.361 & 1985: 11 & 0.312 & 0 & -0.082 \\ & (-5.68) & & (14.14) & & & & (-3.42) \\ \text { Japan } & -0.120 & 1981: 10 & 0.370 & 1986: 04 & -5.094 & 0 & -0.111 \\ & (-7.98) & & (25.29) & & & & (-3.86) \\ \text { Austria } & -0.279 & 1981: 02 & 0.320 & 1986: 04 & -2.500 & 0 & -0.159 \\ & (-20.79) & & (25.07) & & & & (-4.60) \\ \text { Denmark } & -0.276 & 1981: 02 & 0.323 & 1986: 04 & -1.919 & 0 & -0.163 \\ & (-22.35) & & (27.44) & & & & (-4.63) \\ \text { Netherlands } & -0.324 & 1981: 02 & 0.377 & 1986: 04 & -0.658 & 0 & -0.156 \\ & (-23.10) & & (28.21) & & & & (-4.52) \\ \text { Norway } & -0.246 & 1982: 03 & 0.300 & 1986: 04 & -1.952 & 0 & -0.172 \\ & (-20.13) & & (25.08) & & & & (-4.84) \\ \text { Sweden } & -0.288 & 1981: 10 & 0.289 & 1986: 04 & -1.871 & 0 & -0.137 \\ & (-20.95) & & (21.68) & & & & (-4.30) \\ \text { Finland } & -0.211 & 1982: 11 & 0.258 & 1986: 04 & -1.544 & 0 & -0.095 \\ & (-12.71) & & (15.62) & & & & (-3.58) \\ \text { Greece } & -0.263 & 1982: 10 & 0.284 & 1986: 04 & -5.114 & 6 & -0.107 \\ & (-18.53) & & (20.19) & & & & (-2.91) \\ \text { Spain } & -0.274 & 1982: 03 & 0.359 & 1986: 04 & -4.118 & 0 & -0.118 \\ & (-16.83) & & (22.40) & & & & (-3.99)\end{array}$

Notes: See notes to Table 3. 
Table 6: Innovational Outlier Unit-root Tests for WPI-Based Real Exchange Rate Series

$\begin{array}{llllllll}\text { Country } & \delta_{1} & T_{b 1} & \delta_{2} & T_{b 2} & \mu & k & \alpha-1 \\ \text { Canada } & -0.006 & 1977: 10 & 0.005 & 1987: 07 & -0.015 & 11 & -0.084 \\ & (-1.68) & & (2.16) & & & & (-3.32) \\ \text { Germany } & -0.023 & 1981: 02 & 0.035 & 1986: 05 & -0.053 & 0 & -0.085 \\ & (-2.49) & & (3.18) & & & & (-3.37) \\ \text { United Kingdom } & 0.010 & 1977: 08 & 0.016 & 1987: 03 & 0.018 & 11 & -0.079 \\ & (1.36) & & (2.35) & & & & (-3.29) \\ \text { Japan } & 0.021 & 1986: 02 & 0.013 & 1993: 02 & -0.452 & 11 & -0.088 \\ & (2.85) & & (1.72) & & & & (-3.40) \\ \text { Austria } & -0.025 & 1981: 04 & 0.031 & 1986: 02 & -0.234 & 0 & -0.093 \\ & (-2.52) & & (2.98) & & & & (-.3 .46) \\ \text { Denmark } & -0.025 & 1981: 02 & 0.033 & 1986: 07 & -0.184 & 0 & -0.096 \\ & (-2.84) & & (3.34) & & & & (-3.59) \\ \text { Netherlands } & -0.027 & 1981: 02 & 0.036 & 1986: 05 & -0.059 & 0 & -0.087 \\ & (-2.67) & & (3.24) & & & & (-3.42) \\ \text { Norway } & -0.028 & 1982: 05 & 0.036 & 1986: 07 & -0.237 & 9 & -0.121 \\ & (-3.02) & & (3.42) & & & & (-3.85) \\ \text { Sweden } & -0.024 & 1981: 07 & 0.027 & 1986: 07 & -0.179 & 9 & -0.095 \\ & (-2.63) & & (3.00) & & & & (-3.52) \\ \text { Finland } & -0.016 & 1982: 08 & 0.020 & 1985: 12 & -0.105 & 0 & -0.068 \\ & (-2.09) & & (2.46) & & & & (-3.17) \\ \text { Greece } & -0.020 & 1982: 03 & 0.024 & 1986: 07 & -0.451 & 11 & -0.088 \\ & (-2.42) & & (2.89) & & & & (-3.27) \\ \text { Spain } & -0.016 & 1982: 06 & 0.025 & 1986: 02 & -0.345 & 7 & -0.071 \\ & (-1.83) & & (2.43) & & & & (-3.10)\end{array}$

Notes: See notes to Table 4. 


\section{Figure 1: CPI-Based Real Exchange Rates}
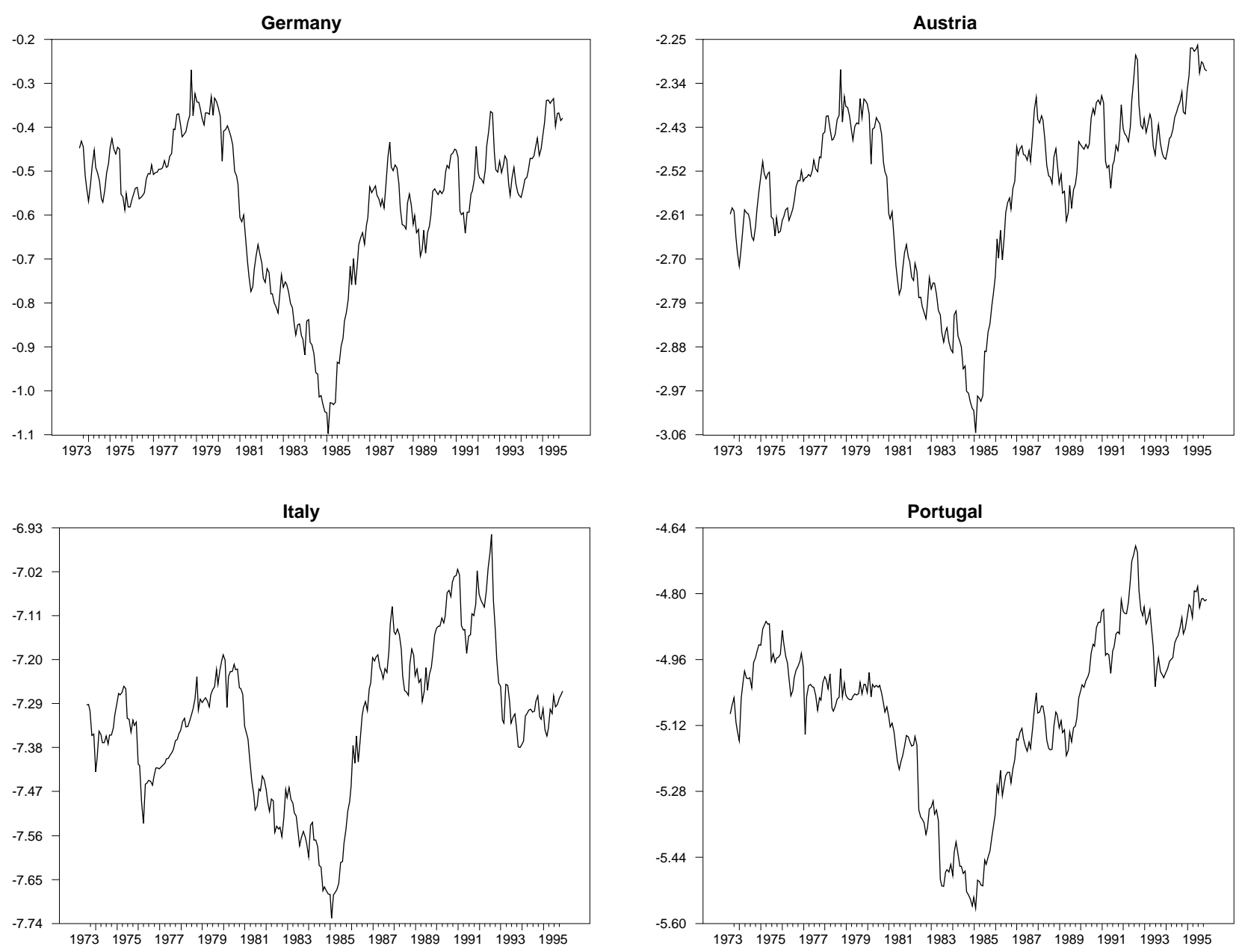


\section{Figure 2: WPI-Based Real Exchange Rates}
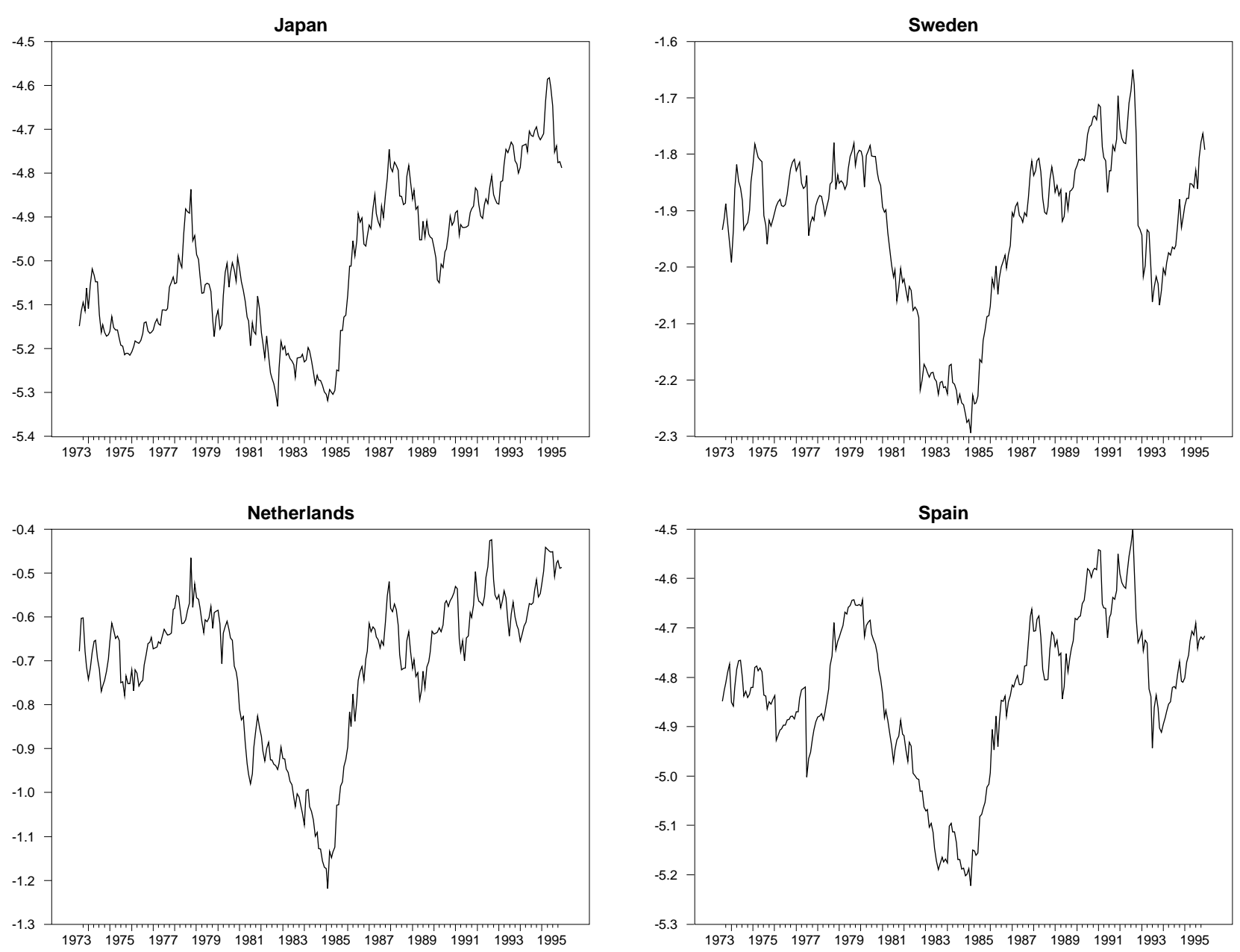